\title{
Lymphocytes, cytokines and adhesion molecules in chronic graft versus host disease
}

Sélim Aractingi, Eliane Gluckman, Caroline Le Goué, Louis Dubertret, Edgardo D Carosella

\begin{abstract}
Aims-To determine which inflammatory and immune pathways are implicated in the development of chronic graft versus host disease (GvHD) and whether differences between these pathways are responsible for the different presentations of chronic GvHD.

Methods-Biopsy specimens of diseased and normal skin were obtained from patients presenting with lichen planuslike and sclerodermatous type chronic GvHD. Expression of epidermal cytokines, adhesion molecules and lymphoid surface markers was analysed by means of immunohistochemistry. Apoptosis was detected using the in situ nick endlabelling method.

Results-In both GvHD lesion types, CD8+ cells predominated in the epidermis, whereas CD4+ cells were the most prevalentin the dermis.Apoptotickeratinocytes were found in diseased skin only and Fas antibodies labelled a considerable number of keratinocytes. The epidermis in both types of lesions expressed interleukin (IL) $1 \alpha$, tumour necrosis factor (TNF) $\alpha$ and intercellular adhesion molecule (ICAM)-1, but dermal vascular cell adhesion molecule (VCAM)-1 expression was restricted to specimens of lichen planuslike GvHD. IL1 $\alpha$ and E-selectin were expressed in normal looking skin of $55 \%$
\end{abstract}

and $80 \%$, respectively, of patients with lichen planus-like GvHD.

Conclusion-The similarity between expression of epidermal cytokines and adhesion molecules (with the exception of VCAM-1) and lymphocyte phenotype in lichen planus-like and sclerodermatous GvHD strongly suggests that the latter occurs as a consequence of the healing process. VCAM-1 distinguishes between lichen planus-like and sclerodermatous lesions. IL $1 \alpha$ and E-selectin are potential early markers of chronic GvHD.

(F Clin Pathol: Mol Pathol 1996;49:M225-M231)

Keywords: graft versus host disease, skin, lymphocytes cytokines, adhesion molecules.

Chronic graft versus host disease (GvHD) is one of the most disabling complications of bone marrow transplantation (BMT). About $30-50 \%$ of transplant recipients still living three months after transplantation will present with features of this disease. ${ }^{12}$ In contrast to acute GvHD, where a cytotoxic reaction driven by donor $\mathrm{T}$ lymphocytes against host antigens has been demonstrated, ${ }^{34}$ the pathogenesis of chronic GvHD is poorly understood. Evidence for an interaction between anti-host and autoimmune phenomena is described frequently, ${ }^{5-10}$ but the precise pathways leading to the development of the lesions are still unclear.
Service de Recherche en Hémato-

Immunologie

(DRM-DSV, CEA),

Hôpital St Louis,

Centre Hayem,

1 Avenue Claude

Vellefaux, 75475 Paris,

France

$S$ Aractingi

E Gluckman

C Le Goué

L Dubertret

E D Carosella

Service de Greffe de

Moelle

E Gluckman

Correspondence to:

Dr S Aractingi.

Accepted for publication 16 April 1996

Table 1 Antibodies used

\begin{tabular}{|c|c|c|}
\hline Antibody & Reactivity & Source \\
\hline \multicolumn{3}{|c|}{ Lymphocyte surface antigens } \\
\hline $\mathrm{CD} 3$ & $\begin{array}{l}\text { T lymphocytes } \\
\text { (CD3 complex associated with } \alpha \beta \text { or } \gamma \delta \mathrm{TCR} \text { ) }\end{array}$ & Dako \\
\hline CD4 & Helper/inducer T lymphocytes & Dako \\
\hline CD8 & Suppressor/cytotoxic lymphocytes & Dako \\
\hline CD16 & Natural killer cells & Dako \\
\hline CD25 & $\begin{array}{l}\text { IL-2R } \\
\text { (Tac; IL-2R } \alpha \text { chain) }\end{array}$ & Dako \\
\hline CD30 & Activated lymphoid cells & Dako \\
\hline CD45RO & Memory T cells & Dako \\
\hline CD56 & Natural killer cells & Dako \\
\hline$\delta$ TCR & $\gamma \delta \mathrm{T}$ cells receptor & Immunotech \\
\hline$\alpha \beta$ TCR & $\alpha \beta$ T cell receptor & Immunotech \\
\hline CD20 & $\mathrm{B}$ cells & Dako \\
\hline Perforin & Perforin expression & Pharmacell \\
\hline CD 95 (Fas) & Apo-Fas protein on target cells & Immunotech \\
\hline \multicolumn{3}{|l|}{ Cytokines } \\
\hline IL $1 \alpha$ & IL1 protein & R\&D Systems \\
\hline IL8 & IL8 protein & R\&D Systems \\
\hline TNF $\alpha$ & TNF protein & R\&D Systems \\
\hline \multicolumn{3}{|c|}{ Adhesion molecules } \\
\hline CD106 & VCAM-1: ligand for VLA-4 cells & Novocastra \\
\hline E-selectin & Endothelial adhesion molecule & Genzyme \\
\hline CD54 & ICAM 1: ligand for LFA-1 and Mac-1 & Novocastra \\
\hline
\end{tabular}

\footnotetext{
TNF $=$ tumour necrosis factor.
} 

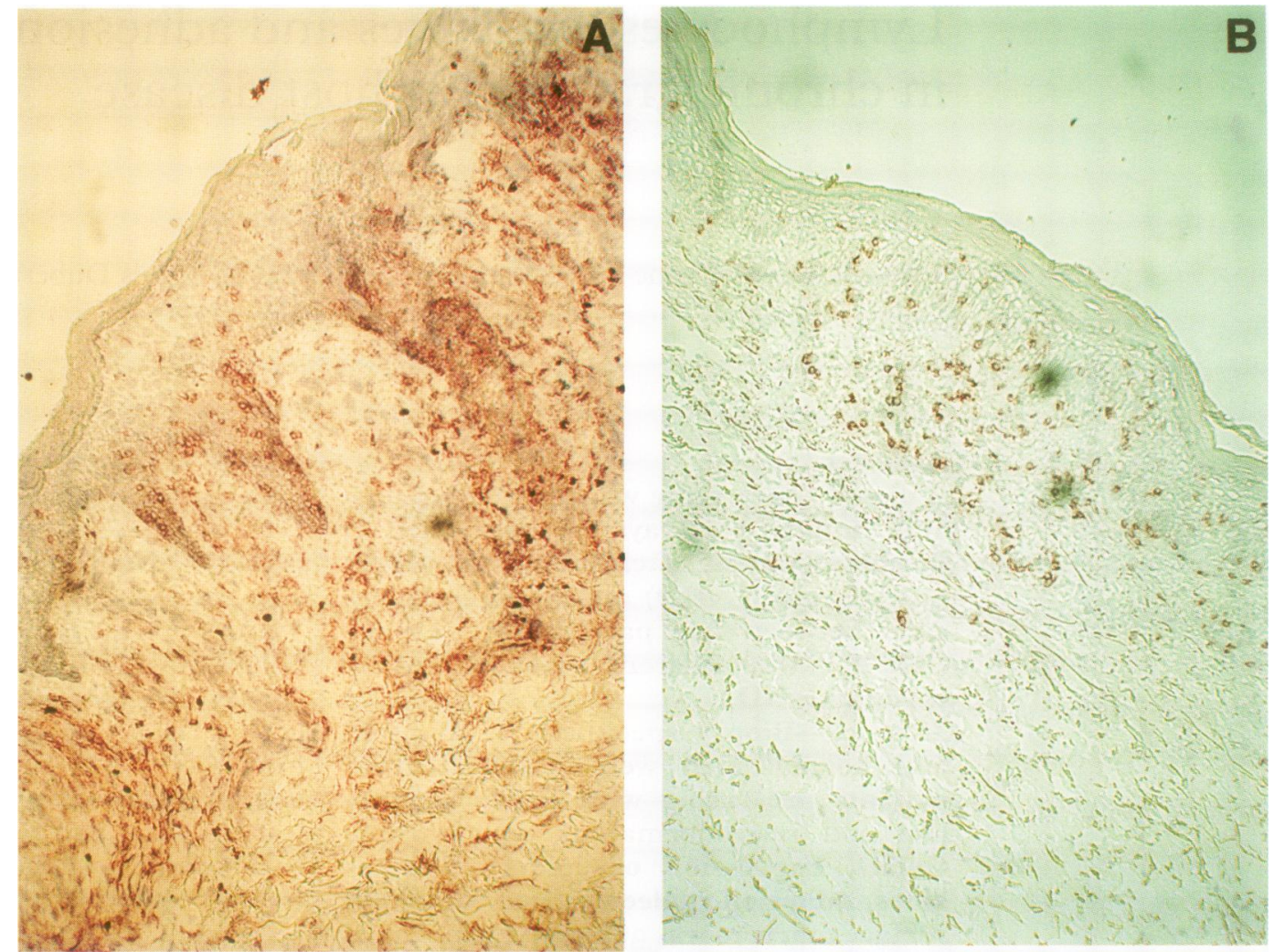

Figure 1 (A) CD8 + infiltrate in superficial dermis and epidermis in a patient with lichen planus-like GvHD (original magnification $\times 100)$. (B) CD8 + cells in sclerodermatous GvHD (original magnification $\times 100$ ).

The skin is the major target organ in chronic GvHD and patients may present with lichen planus-like or sclerodermatous lesions, or both. The importance of the interactions between keratinocytes, endothelium and lymphocytes in triggering or amplifying cutaneous inflammation has been underlined in several skin diseases. ${ }^{11-16}$ As chronic GvHD is characterised by a cutaneous lymphocytic infiltration, these interactions may also play a role in its development. In order to determine which pathways are implicated in chronic GvHD and whether the differences in chronic cutaneous GvHD could be secondary to differences in these pathways, the expression of skin adhesion molecules and cytokines was analysed. The phenotype of the lymphoid infiltrating cells

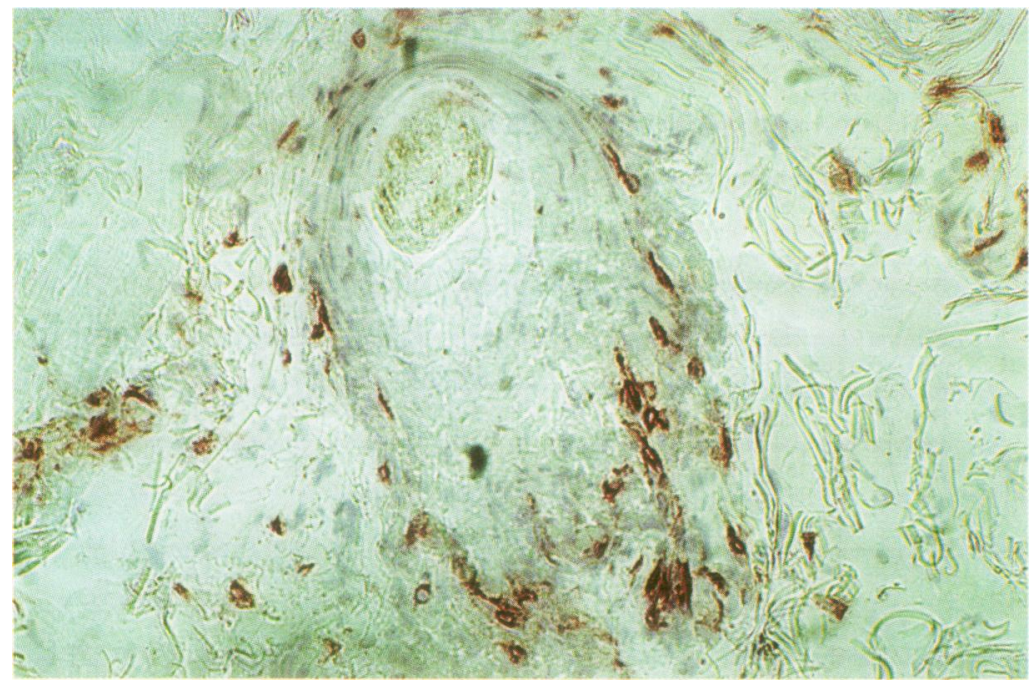

Figure 2 Immunohistochemical labelling of a hair follicle with CD8 antibody (original magnification $\times 250$ ). and the mechanisms of epidermal damage were also investigated.

\section{Methods}

Transplant recipients who presented between October 1993 and October 1994 with cutaneous lichen planus-like or de novo sclerodermatous lesions were examined by one of us (SA). Patients were considered to have lichen planuslike GvHD if they presented with the typical physical findings and if examination of tissue sections showed epidermal hyperplasia, eosinophilic body formation and a lymphocytic infiltrate in the epidermis and dermis. Patients were considered to have sclerodermatous GvHD if they presented with typical symptoms, if there was no history of lichen planus lesions at the sclerotic sites and if histopathology demonstrated epidermal atrophy, basement membrane flattening and fibrosis of the papillary dermis.

\section{CONTROLS}

Biopsy specimens were taken of the diseased and healthy skin. Each specimen was divided in two: one half was embedded in OCT and snap frozen in liquid nitrogen; the other was fixed in formalin, embedded in paraffin wax and stained with haematoxylin and eosin.

Biopsy specimens were obtained from patients who received grafts more than three months previously, who had other skin diseases (one case of late porphyria, two cases of adverse reaction to drugs, one case of solar erythema) or healed lichen planus-like GvHD (one case), and from patients who had undergone total body irradiation and autologous BMT but who had no skin abnormalities 
Table 2 Lymphocyte surface antigens in chronic GvHD

\begin{tabular}{|c|c|c|c|c|c|c|c|}
\hline \multirow[t]{2}{*}{ Histological diagnosis } & \multirow{2}{*}{$\begin{array}{l}\text { Lymphocytic } \\
\text { infiltration }\end{array}$} & \multirow{2}{*}{$\begin{array}{l}T \text { cells } \\
C D 3 \\
C D 4 \\
C D 8\end{array}$} & \multicolumn{2}{|c|}{$T C R$} & \multirow{2}{*}{$\begin{array}{l}\text { Activation } \\
C D 25+ \\
C D 30+ \\
C D 45 R O+\end{array}$} & \multirow{2}{*}{$\begin{array}{l}N K \\
C D 16 \\
C D 56\end{array}$} & \multirow{2}{*}{$\begin{array}{l}B \text { cells } \\
C D 20\end{array}$} \\
\hline & & & $\alpha \beta$ & $\gamma \delta$ & & & \\
\hline Lichen planus-like & +++ & +++ & + & - & + & - & - \\
\hline Sclerodermatous & ++ & ++ & + & - & + & - & - \\
\hline Normal skin & - & - & - & - & - & - & - \\
\hline
\end{tabular}

(four cases). Normal skin removed during breast plastic surgery was also analysed (four cases).

\section{IMMUNOHISTOCHEMISTRY}

Cryostat sections $(4-6 \mu \mathrm{m})$ were examined immunohistochemically using an indirect biotin antibody conjugated technique. Sections were fixed in cold acetone and incubated with normal serum for 30 minutes at room temperature. Sections were then incubated with each of the specific antibodies directed against the different antigens listed in table 1 for 30 minutes. The sections were washed in phosphate buffered saline (PBS) and then incubated with a biotin conjugated antibody directed against the primary antibody. AEC was used as the chromogen. Lymphocytic infil-

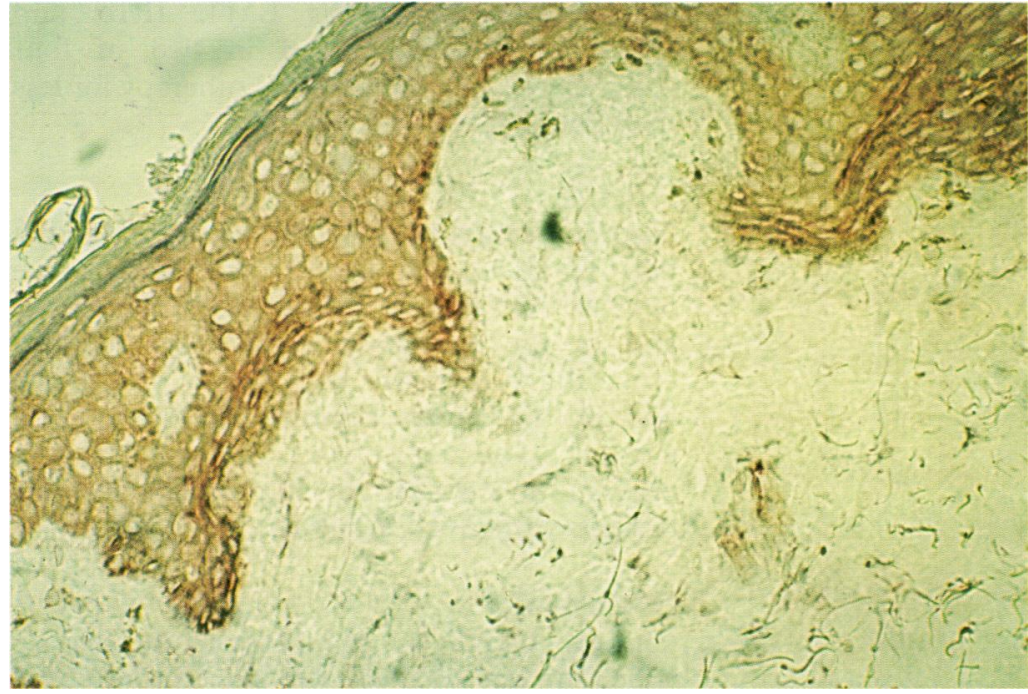

Figure 3 Diffuse labelling of keratinocytes with anti-Fas antigen in chronic lichen planus-like GvHD (original magnification $\times 250$ ).

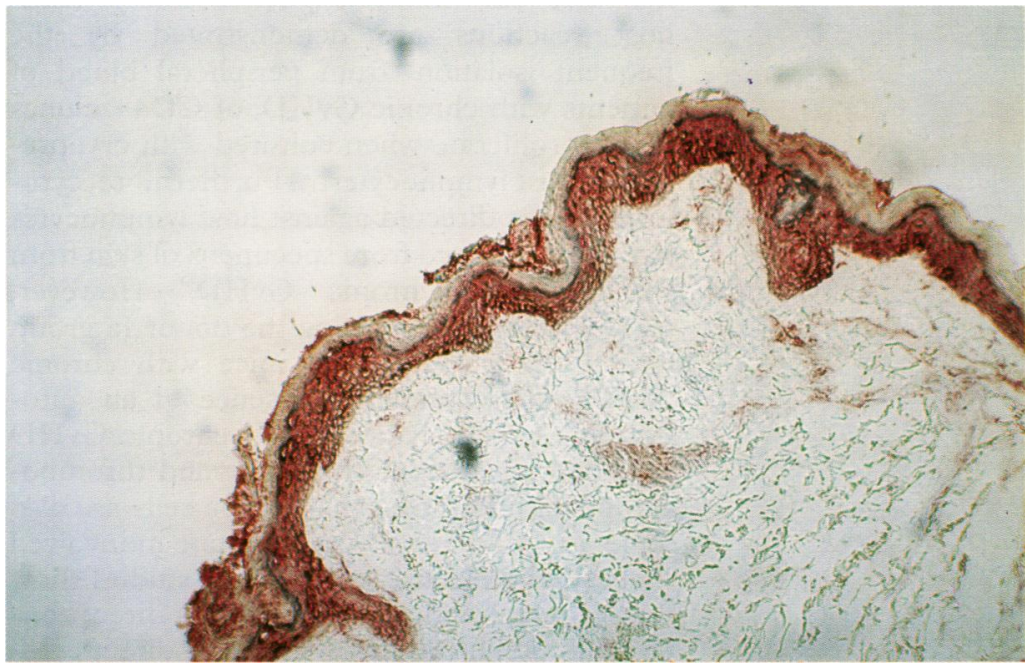

Figure 4 Expression of IL1 $\alpha$ in epidermal keratinocytes (original magnification $\times 100$ ) tration was scored semiquantitatively as follows: - , no labelled cells present; + , scattered labelled cells; ++ , moderate infiltration; and +++ , dense infiltration.

Negative controls included substitution of the primary antibody by an antibody of an irrelevant specificity but of the same IgG isotype. Positive controls included samples of psoriasis, tuberculoid leprosy, $\mathrm{T}$ and $\mathrm{B}$ cell lymphoma, and adverse drug reactions.

\section{LABELLING OF APOPTOTIC CELLS}

Apoptosis was detected in diseased and normal skin by end labelling fragmented DNA using the ApopTag kit (Oncor, Maryland, USA). ${ }^{17}$ Briefly, paraffin wax sections were first deparaffinised and digested with proteinase $\mathrm{K}$. Cryostat sections were fixed in neutral buffered formalin and then post-fixed in ethanol:acetic acid $(2: 1)$ for five minutes at room temperature. Slides were incubated in a humidified chamber at $37^{\circ} \mathrm{C}$ for one hour in a solution containing terminal deoxynucleotidyl transferase (TDTase), digoxigenin labelled dUTP and dATP. The sections were then washed and incubated with the peroxidase labelled antidigoxigenin antibody for 30 minutes. The reaction products were developed with AEC, washed again and the slides counterstained with haematoxylin and eosin. The sections were then examined under a Leitz orthoplan microscope.

\section{Results}

HISTOLOGY

On histological examination 13 patients had typical features of lichen planus-like GvHD and five of sclerodermatous GvHD. Lymphocytic infiltration was present in both forms. Epidermal abnormalities were not present and lymphocytes were observed infrequently in the superficial dermis in normal skin of the same patients. The diagnoses of skin diseases in control patients were also confirmed histologically.

\section{IMMUNOHISTOCHEMISTRY}

Scattered CD3 + cells were present in the dermis of normal skin in all patients with chonic GvHD. A CD3 + infiltrate was observed in sections of diseased skin in both patient groups. CD4+ and CD8+ subsets were found. However, on semiquantitative analysis, the CD4+ CD8+ infiltrate was more dense in patients with lichen planus-like GvHD (table 2). In both types of GvHD, CD8+ lymphocytes predominated in the epidermis whereas CD4+ cells were more prevalent in the dermis (table 2; figs $1 \mathrm{~A}$ and $1 \mathrm{~B}$ ). CD8+ cells were also found also in follicular epithelium in those with lichen planus-like GvHD (fig 2). T cells 
Table 3 Cytokines and adhesion molecules expressed in chronic GvHD

\begin{tabular}{|c|c|c|c|c|}
\hline & \multicolumn{2}{|c|}{ Lichen planus-like GvHD } & \multicolumn{2}{|c|}{ Sclerodermatous GvHD } \\
\hline & Diseased & Normal & Diseased & Normal \\
\hline $\mathrm{TNF} \alpha$ & $13 / 13$ & $3 / 9$ & $4 / 5$ & $0 / 4$ \\
\hline $\operatorname{IL} 1 \alpha$ & $13 / 13$ & $7 / 9^{\star}$ & $5 / 5$ & $0 / 5^{\star}$ \\
\hline IL8 & $13 / 13$ & 9/9 & $5 / 5$ & $4 / 5$ \\
\hline VCAM-1 & $12 / 13^{\star \star}$ & $1 / 10$ & $0 / 5^{\star \star}$ & $0 / 5$ \\
\hline E-selectin & $12 / 13$ & $6 / 9+$ & $3 / 5$ & $0 / 5 \dagger$ \\
\hline CD54 & $13 / 13$ & $0 / 9$ & $4 / 5$ & $0 / 5$ \\
\hline
\end{tabular}

${ }^{\star} \mathrm{p}<0.05 ;{ }^{\star \star} \mathrm{p}<0.01 ; \mathrm{fp}=0.062$

had the following phenotype: $\mathrm{T}$ cell receptor (TCR) $\alpha \beta+$, TCR $\gamma \delta-$, CD25+, CD $30+$, $\mathrm{CD} 45 \mathrm{RO}+$. B lymphocytes and natural killer cells were not detected. Perforin expression was not seen. Patients who experienced an adverse reaction to drugs (CD16+, CD56+), those with B cell lymphoma (CD20+) or leprosy (TCR $\gamma \delta+$, perforin + ) served as controls. In lichen planus-like GvHD diffuse staining of keratinocyte membranes was noted with Fas antibody (fig 3). This expression was restricted to basal layer in sclerodermatous GvHD. Fas expression was not observed in normal skin.

Table 3 and figs 4-7 summarise cytokine and adhesion molecule expression. Interleukin (IL)

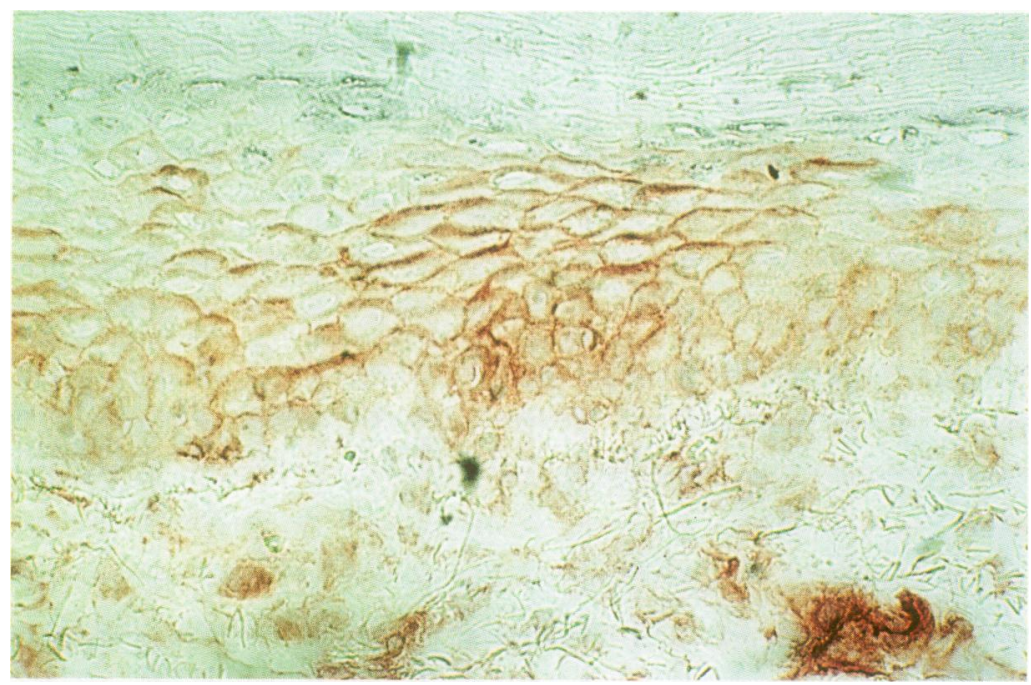

Figure 5 Membrane expression of CD54 in keratinocytes from diseased skin (original magnification $\times 250$ )

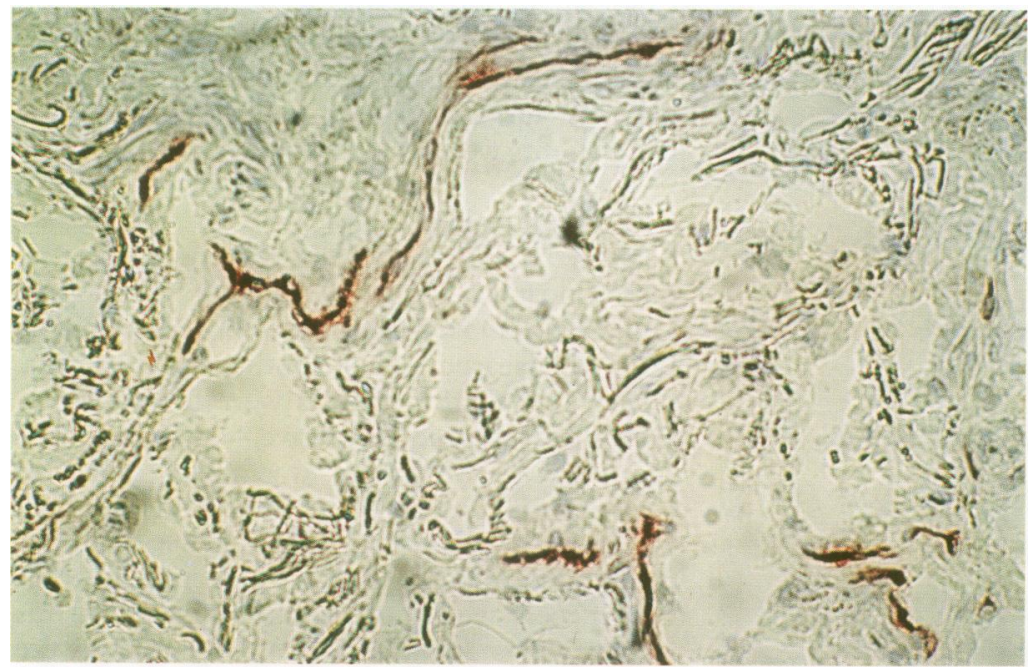

Figure 6 Regular distribution of VCAM-1 in the dermis of patients with lichen planus-like GvHD (original magnification $\times 100$ )
$1 \alpha$ and tumour necrosis factor (TNF) $\alpha$ were nearly always expressed in diseased epidermis of both types of GvHD. IL8 was expressed in the cytoplasm of all keratinocytes in diseased and healthy skin of patients in a pattern identical with that in normal controls; the intercellular spaces were unstained (data not shown). expression of vascular cell adhesion molecule (VCAM)-1 in lichen planus-like and sclerodermatous GvHD differed significantly ( $p<0.01$; Fisher's exact test). IL $1 \alpha$ was expressed in seven of nine biopsy specimens of normal skin from patients with lichen planus-like GvHD, but not in normal skin of patients with sclerodermatous GvHD ( $p<0.05$; Fisher's exact test). Expression of E-selectin was observed in six of nine biopsy specimens of normal skin from patients with lichen planus-like GvHD but not in normal skin of patients with sclerodermatous GvHD ( $p=0.062$; Fisher's exact test).

\section{CONTROLS}

VCAM-1 expression was not observed in any of the allogeneic BMT recipients with other skin conditions. IL $1 \alpha$ and E-selectin were expressed in two of five of these patients. A lymphocytic infiltrate was not observed in patients who underwent total body irradiation followed by autologous BMT. IL $1 \alpha$ and E-selectin were expressed in two of four patients who had received radiotherapy for less than one year.

APOPTOSIS

Numerous keratinocytic nuclei were labelled in both GvHD types (fig 8A). Labelled keratinocytes were present mainly in the basal layer and in the suprabasal to a lesser degree, especially in patients with lichen planus-like GvHD. Follicular keratinocytes were also labelled (data not shown). Staining was not observed in controls and in normal skin from patients with $\mathrm{GvHD}$ (fig $8 \mathrm{~B}$ ).

\section{Discussion}

Chronic GvHD is a multisystemic disease which mainly involves the skin, mouth and liver. Its pathogenesis seems to be the consequence of a complex interaction between antihost and auto-immune phenomena. ${ }^{5-10}$ Antihost reactions are demonstrated by the frequent isolation, from peripheral blood of patients with chronic GvHD, of CD4+ clones which proliferate when cultured with cryopreserved host lymphocytes. ${ }^{56}$ Furthermore, cytotoxic clones directed against host lymphocytes have been isolated from specimens of skin from patients with chronic GvHD. ${ }^{7}$ However, CD4+ clones recognising the donor Ia group have been isolated from mice with chronic GvHD, suggesting the presence of an autoimmune effect. ${ }^{8}$ Patients with chronic GvHD may develop lymphoid atrophy and thrombocytopenia, indicating that donor cells are also targeted. ${ }^{9} \mathrm{CD} 8+$ cells predominate in involved tissues ${ }^{18}$ and electron microscopy studies show that some mononuclear cells are in direct contact with keratinocytes, ${ }^{19}$ implying direct cytotoxicity. Our results demonstrate that infiltrat- 


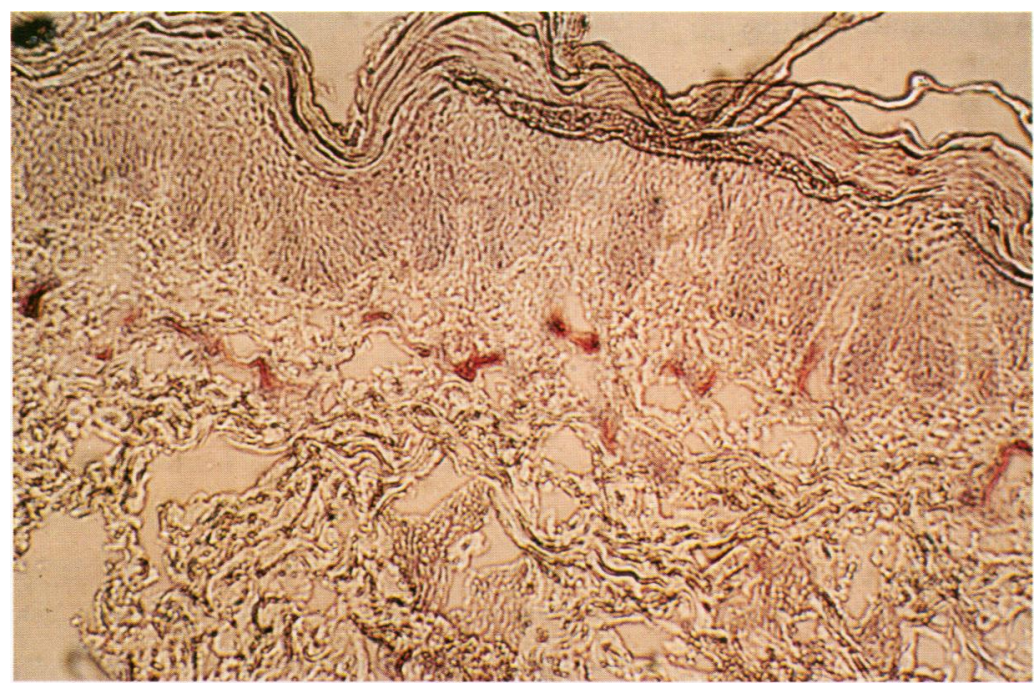

Figure $7 \quad$ E-selectin expression in dermal vessels (original magnification $\times 250$ )

ing lymphocytes in lichen planus-like and sclerodermatous GvHD have a similar phenotype and distribution pattern. Indeed, CD8+ cells predominated in the epidermis and CD4+ cells in the dermis. The presence of CD8+ cells at the site of cellular damage suggests strongly that these are the effector cells. Invasion of follicle walls by $\mathrm{CD} 8+$ cells in lichen planus-like lesions, very similar to the changes described in acute $\mathrm{GvHD},{ }^{20}$ is in accordance with this hypothesis. The possibility that these observations are the consequence of reactions directed against epidermal stem cells, which are more numerous in lower follicles, ${ }^{21}$ could not, however, be demonstrated in this study.

Perforin, part of the major cytotoxicity pathway, ${ }^{22}$ does not seem to play a role in chronic
GvHD. Identical results in chronic GvHD were reported recently by Takata. ${ }^{23}$ Perforin, however, is expressed by lymphocytes in acute GvHD. ${ }^{23}$

Keratinocytes from patients with chronic GvHD expressed Fas antigen. This molecule is the receptor for Fas ligand, which may be secreted by some cytotoxic $\mathrm{T}$ lymphocytes. ${ }^{24}$ Keratinocytes do not secrete Fas constitutively, but have the ability to do so in certain circumstances, such as in classic lichen planus. ${ }^{25}$ Epidermal cell apoptosis, therefore, could be secondary to the secretion of Fas ligand by $T$ lymphocytes acting on keratinocytes. Interestingly, natural killer cells and $\mathrm{T} \gamma \delta$ cells, which play a role in acute GvHD, ${ }^{26}{ }^{27}$ do not seem to be implicated in the chronic form.

IL $1 \alpha$, TNF $\alpha$ and CD54 were expressed in diseased epidermis and E-selectin in dermal vessels. These molecules can be chemotactic for $\mathrm{T}$ cells and permit strong adhesion of lymphocytes to endothelium or keratinocytes and therefore may contribute to the development of cutaneous GvHD. TNF $\alpha$, E-selectin and VCAM-1 are expressed in skin specimens of patients with systemic sclerosis, an autoimmune disease which is clinically very similar to sclerodermatous GvHD. ${ }^{28}{ }^{29}$ The lack of VCAM-1 expression in the specimens of sclerodermatous GvHD in the present study suggests that different pathogenetic mechanisms are involved in these two diseases. Our results show that VCAM-1 expression was restricted to lichen planus-like lesions. In classic lichen planus, as well in acute GvHD, VCAM-1 expression is highly upregulated on dermal endothelial cells. ${ }^{30-32}$ VCAM-1 is a member of the immunoglobulin superfamily which mediates adhesion of memory $T$ lym-
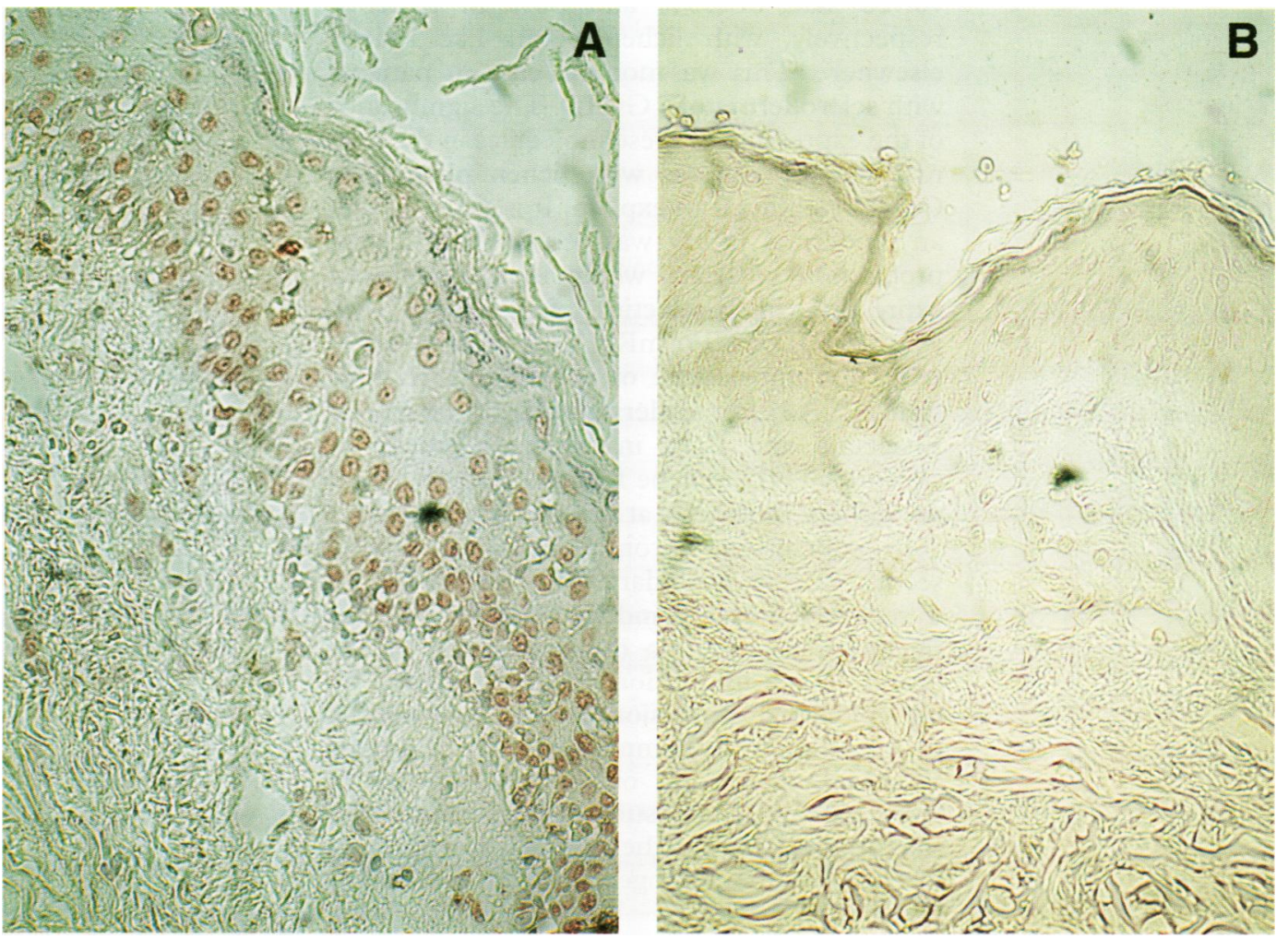

Figure 8 (A) Fragmentation of nuclear DNA is evident in keratinocytes from a patient with lichen planus-like GvHD. (B) No DNA fragmentation was seen in uninvolved skin from the same patient. 
phocytes expressing VLA-4 to endothelium. ${ }^{33}$ TNF $\alpha$ induces the expression of both E-selectin and VCAM-1 molecules ${ }^{34}$ on skin endothelial cells, whereas IL4 triggers selective expression of VCAM-1..$^{35}$ It has recently been shown that administration of antibodies directed against IL4 inhibits features of GvHD in mice. ${ }^{37}$ As VCAM-1 was expressed in lichen planus-like GvHD only, where infiltrating $T$ lymphocytes were present, and never in healthy skin (although IL $1 \alpha$ and TNF $\alpha$ were sometimes expressed by keratinocytes), VCAM-1 expression could therefore occur secondary to the lymphocytic infiltration and possibly to IL4 expression. Interestingly, Norton and Sloane reported that VCAM-1 was expressed only in patients who developed acute GvHD at a later date. $^{32}$

Sclerodermatous GvHD, therefore, is characterised by the production of adhesion molecules and cytokines by keratinocytes and by epidermal apoptosis and lymphocytic infiltration. These features are similar, although milder, than those found in lichen planus-like GvHD. The nature of the $T$ cell infiltrate is also very similar in both GvHD types. These results suggest strongly that de novo sclerodermatous GvHD may represent healing of discrete epidermal events. This hypothesis is in accordance with previous studies showing that the development of sclerotic lesions in a late event in chronic GvHD ${ }^{10}{ }^{38-40}$ and with clinical reports of sclerodermatous GvHD developing at sites of lichen planus lesions. ${ }^{41}$ The localisation of fibrosis in superficial dermis ${ }^{42}$ and the sequential deposition of collagen III and $\mathrm{I}^{42}$ in sclerodermatous GvHD, very similar to the processes occurring during tissue repair, ${ }^{43}$ also support this hypothesis.

E-selectin and IL1 $\alpha$ were expressed in uninvolved skin of $55 \%$ and $80 \%$ of patients, respectively, with lichen planus-like lesions elsewhere. This was not the case in patients with sclerodermatous GvHD. The significance of the expression of these molecules in the normal skin of patients with lichen planus-like $\mathrm{GvHD}$ is difficult to explain. It is possible that an epidermal injury was responsible for the production of IL $1 \alpha$, which in turn induced expression of E-selectin. ${ }^{34}$ In patients with acute GvHD TNF $\alpha$ mRNA expression supersedes the appearance of a lymphocytic infiltrate. ${ }^{44}{ }^{45} \mathrm{~A}$ better understanding of the role of E-selectin and IL $1 \alpha$ in the pathogenesis of chronic GvHD may be forthcoming on analysis of these molecules at day 100 after BMT.

In conclusion, chronic cutaneous GvHD seems to occur secondary to the infiltration by $T$ cells which in turn induce apoptosis of keratinocytes, possibly via the production of Fas ligand. $T$ cell infiltration may be triggered by the epidermal expression of IL $1 \alpha$ and may in turn amplify inflammation by inducing VCAM-1 expression on dermal vessels. In some patients, this results in the formation of sclerotic lesions. Further studies are required to elucidate the pathogenesis of this debilitating chronic disease.

This work was supported in part by Ligue contre le cancer-Comité de Paris and ARTM.
1 Parkman R. Graft-versus-host disease. Ann Rev Med 1991;

42:189-97.
2 Atkison K, Horowitz M, Deeg J, Gale RP, van Bekkun DW, Gluckman E, et al. Risk factors for chronic graft versus host disease. Blood 1990;175:2459-64.

3 Gaschet J, Mahé B, Milpied N, Devilder MC, Dreno B, Bignon JD, et al. Specificity of T-cell invading the skin during acute graft-versus-host disease after semi-allogeneic bone-marrow transplantation. $f$ Clin Invest 1993;91:12-20.

4 Kasten Sportes CM, Masset M, Varrin F, Devergie A, Gluckman E. Phenotype and function of T-lymphocyte the skin during graft-versus-host disease following allogenic skin during graft-versus-host disease following allogenic
bone-marrow transplantation Transplantation 1989; 47:621-4.

5 Goulmy E, Gratama JW, Blokland E, Zwaan FE, van Rood JJ. Minor transplantation antigen detected by MHC restricted cytotoxic $T$ lymphocytes during graft versus host disease. Nature 1983;302:159-61.

6 Tsoi MS, Storb R, Dobbs S, Medill L, Thomas ED. Cell mediated immunity to non-HLA antigens of the host by donor lymphocytes in patients with chronic graft-versushost disease. F Immunol 1980;125:2258-62.

7 Atkinson K. Pathogenesis of human chronic graft-vs-host disease. In: Burakoff SJ, Deeg HJ, Ferrara J, Atkinson K, eds. Graft-vs-Host-Disease. Hematology. Vol 12. New York: eds. Graft-vs-Host-Disease. Hemat

8 Parkman R. Clonal analysis of murine graft versus host disease. F Immunol 1986;136:3543-8.

9 Anasetti C, Rybka W, Sullivan KM, Banaji M, Slichter SJ. Graft-v-host disease is associated with autoimmune-like thrombocytopenia. Blood 1989;73:1054-8.

10 Shulman HM, Sullivan KM, Weiden PL MacDonald GB, Striker G, Sale GE, et al. Chronic graft-versus-host syndrome in man. A long-term clinicopathologic study of 20 Seattle patients. Am $\mathcal{F}$ Med 1980;69:204-17.

11 Barker JNWN, Mitra RS, Griffiths CEM, Dixit VM, Nickoloff BJ. Keratinocytes as initiators of inflammation. Lanoloff BJ. Keratinocytes
cet 1991;337:211-14.

12 Bos JD, Kapsenberg ML. The skin immune system: progress in cutaneous biology. Immunol Today 1993; 14:75-8

13 Norris DA. Cytokine modulation of adhesion molecules in the regulation of immunologic cytotoxicity of epidermal targets. F Invest Dermatol 1990;95:111S-20S.

14 Dustin ML, Singer KH, Tuck DT, Springer TA. Adhesion of $\mathrm{T}$ lymphoblasts to epidermal keratinocytes is regulated by interferon and is mediated by ICAM1. F Exp Med 1988;167:1323-6

15 Griffiths CEM, Voorhees JJ, Nickoloff BJ. Characterization of intercellular adhesion molecule-1 and HLA-DR expression in normal and inflammed skin: Modulation by sion in normal and inflammed skin: Modulation by
recombinant gamma-interferon and tumor necrosis factor. recombinant gamma-interferon and tum
$\mathcal{F}$ Am Acad Dermatol 1989;20:17-29.

16 Norton J, Sloane JP. ICAM-1 on epidermal keratinocytes in cutaneous graft-versus-host disease. Transplantation 1991; 51:1203-6.

17 Gavrieli Y, Shemen Y, BenSasson SA. Identification of programmed cell death in situ via specific labelling of nuclear DNA fragmentation. $\mathcal{F}$ Cell Biol 1992;119:493-501.

18 Atkinson K, Munro V, Vasak E, Biggs JC. Mononuclear cell subpopulation in the skin defined by monoclonal antibodies after HLA-identical sibling marrow transplantation. $\mathrm{Br}$ ies after HLA-identical sibling

19 Fuji H, Oshashi $M$, Nagura H. Immuno-histochemical analysis of oral lichen planus-like eruption in graft-versushost disease in man. F Immunol 1978;120: 1485-92.

20 Murphy GF, Lavker RM, Whitaker D, Korngold $R$. Cytotoxic folliculitis in GVHD. Evidence for stem cell injury. F Cutan Pathol 1991;18:309-14.

21 Rochat A, Kobayashi K, Barrandon Y. Location of stem cells of human hair follicles by clonal analysis. Cell 1994; 76:1063-73.

22 Kagi D, Ledermann B, Burki K, Seiler P, Odermatt B, Olsen $\mathrm{KJ}$, et al. Cytotoxicity mediated by $\mathrm{T}$ cells and natural $\mathrm{KJ}$, et al. Cytotoxicity mediated by $\mathrm{T}$ cells and natural
killer cells is greatly impaired in perforin deficient mice. killer cells is greatly im
Nature 1994;369:31-7.

23 Takata $M$. Immunohistochemical identification of perforin positive cytotoxic lymphocytes in graft versus host disease. Am $\mathcal{f}$ Clin Pathol 1995;103:324-9.

24 Rouvier E, Luciani MF, Golstein P. Fas involvement in Ca independent $\mathrm{T}$ cell mediated cytotoxicity. $\mathcal{F}$ Exp Med 1993;177:195-200.

25 Sayama K, Yonehara S, Watanabe Y, Miki Y. Expression of Fas antigen on keratinocytes in vivo and induction of apoptosis in cultured keratinocytes. F Invest Dermatol 1994; 103:330-4.

26 Acevedo A, Aramburu J, Lopez J, fernandez Herrera J, Fernandez-Ranada JM, Lopez-Botet $M$. Identification of natural killer cells in lesions of human cutaneous GVHD: expression of a novel NK associated surface antigen (Kp43) in mon.

27 Schattenfroh NC, Hoffman RA, McCarthy SA, Simmons RL. Phenotypic analysis of donor cells infiltrating the small intestinal epithelium and spleen during graft versus host disease. Tranplantation 1995;59:268-73

28 Koch AE, Kronfeld-Harrington LB, Szeckanez Z, Cho $M M$, Haines GK, Harlow LA, et al. In situ expression of cytokines and cellular adhesion molecules in the skin of patients with systemic sclerosis. Their role in early and late disease. Pathobiology 1993;61:239-46.

29 Sollberg S, Peltonen J, Uitto J, Jimenez SA. Elevated expression of beta 1 and beta 2 integrins, intercellular adhesion molecule-1 and endothelial leukocyte adhesion molecule-1 
in the skin of patients with systemic sclerosis of recent onset. Arthritis Rheum 1992;35:290-8.

30 Groves RW, Ross EL, Barker JNWN, MacDonald DM. Vascular adhesion molecule-1: expression in normal and diseased skin and regulation in vivo by interferon gamma. $f$ Am Acad Dermatol 1993;29:67-72.

31 Norton J, Sloane JP, Al-Saffar N, Haskard DO. Vessel associated adhesion molecules in normal skin and acute graftversus-host disease. 7 Clin Pathol 1991;44:586-91

32 Norton J, Sloane JP. A prospective study of cellular and immunologic changes in skin of allogeneic bone marrow recipients. Am f Clin Pathol 1994;101:597-602.

33 Adams DH. Leucocyte endothelial interactions and regulation of leucocyte migration. Lancet 1994;ii:831-6.

34 Bevilacqua MP. Endothelial leukocyte adhesion molecules. Annu Rev Immunol 1993;11:767-84.

35 Thornhill MH, Kyan Aung U, Haskard DO. IL4 increases human endothelial cell adhesiveness for $\mathrm{T}$ cells but not neutrophils. F Immunol 1990;144:3060-4.

36 Swerlick RA, Lee KH, Li L, Sepp NT, Caughman SW, Lawley TJ. regulation of vascular cell adhesion molecule-1 on human dermal microvascular endothelial cells. f Immuno 1992;149:698-705.

37 Ushiyama C, Hirano T, Miyajima H, Okumura K, Ovary Z, Hashimoto $\mathrm{H}$. Anti-IL 4 antibody prevents graft versus host disease in mice after bone

38 Shulman H, Sale G, Lerner K, Barker A, Weiden P, Sullivan
$\mathrm{K}$, et al. Chronic cutaneous graft versus host disease in man. Am 7 Pathol 1978;92:545.

39 Sullivan KM, Shulman HM, Storb R, Weiden PL Witherspoon RP, MacDonald GB, et al. Chronic graft versus host disease in 52 patients: adverse natural course and successful treatments with combination immunosuppression. Blood 1981;57:267-76.

40 Volc-Platzer B, Stingl G. Cutaneous graft-vs-host disease. In: Burakoff SJ, Deeg HJ, Ferrara J, Atkinson K, eds. Graft-vs-Host-Disease. Hematology. Vol 12. New York: Marcel Dekker, 1990:245-54.

41 Chosidow O, Bagot M, Vernant JP, Roujeau JC, Cordonnier $\mathrm{C}$, Kuentz M, et al. Sclerodermatous chronic graft versus host disease. $\mathcal{J}$ Am Acad Dermatol 1992;26:49-55.

42 Janin-Mercier A, Devergie A, VanCauwenberge D, Saurat $\mathrm{JH}$, Bourges $\mathrm{M}$, Lapiere $\mathrm{CM}$, et al. Immunohistologic and ultrastructural study of the sclerotic skin versus host disease in man. Am f Pathol 1984;115:296306.

43 Bailey AJ, Bazin S, Delaunay A. Changes in the nature of the collagen during development and resorption of granulation tissue. Biochem Biophys Acta 1973;328:383-90.

44 Rowbottom AW, Norton J, Riches PG, Hobbs JR, Powles RL Sloane JP. Cytokine gene expression in skin and lymphoid organs in human graft versus host disease. $f$ Clin Pathol 1993;46:341-4.

45 Piguet PF, Grau GE, Allet B, Vassalli P. Necrosis factor-cachectin is an effector of skin and gut lesions of the factor-cachectin is an effector of skin and gut lesions of the 166:1280-9. 